A RCHIWA, BIBLIOTEKI

I MUZEA KOŚCIELNE 111 (2019)

https://doi.org.10.31743/abmk.2019.111.08

\author{
KS. ŁUKASZ KRUCKI*_-GNIEZNO
}

\title{
STATUT I REGULAMIN BRACTWA ŚW. ANNY W WARSZAWIE Z 1946 R.
}

\begin{abstract}
Streszczenie
Prymas August Hlond obejmując w 1946 roku archidiecezję warszawską, złączoną na mocy unii personalnej $\mathrm{z}$ archidiecezją gnieźnieńską, pragnął odnowić życie religijnie i moralnie wiernych (głównie studentów i ludzi związanych ze środowiskiem akademickim), którzy zamieszkiwali zniszczoną działaniami wojennymi stolicę. W tym celu postanowił wskrzesić bractwo św. Anny, posiadające tradycję sięgającą XVI wieku, i nadać mu status prawny odpowiadający aktualnemu prawu kościelnemu. Na przedstawiony mu projekt ustaw, datowany na 8 grudnia 1946 roku, osobiście naniósł poprawki. Dzięki temu bractwo św. Anny uzyskało oparcie prawne, a jednocześnie pozyskało protektora $\mathrm{w}$ osobie prymasa Polski. Sprawiło to, że mogło się ono rozwijać wśród społeczności akademickiej i inteligenckiej stolicy, a konstytutywne cele - krzewić ideę katolicyzmu w społeczeństwie oraz tworzyć odpowiednie środowisko dla odnowy moralności chrześcijańskiej, zdeprawowanej przez okupacyjną rzeczywistość. Nie były to jednak zadania łatwe, zważywszy na powojenną rzeczywistość rodzącego się w Polsce komunistycznego państwa.
\end{abstract}

Słowa kluczowe: bractwa kościelne; statuty i regulaminy brackie; katolicyzm; August Hlond; bractwo św. Anny; inteligencja katolicka; duszpasterstwo akademickie

Prymas August Hlond obejmując w 1946 roku złączoną właśnie z archidiecezją gnieźnieńską - na mocy unii personalnej - archidiecezję warszawską, zdawał sobie sprawę z tragizmu, w jakim znajdowało się polskie społeczeństwo po zakończeniu

\footnotetext{
* Ks. Łukasz Krucki - dr historii Kościoła; zastępca dyrektora Archiwum Archidiecezjalnego w Gnieźnie; wykładowca w Prymasowskim Wyższym Seminarium Duchownym w Gnieźnie; e-mail: krucki@op.pl https://orcid.org/0000-0003-2972-9113
} 
II wojny światowej ${ }^{1}$. Dramatyzm dotykający także jego diecezjan wynikał zarówno z dojmującego doświadczenia przeżytej wojny, jak i nowego porządku zaprowadzanego w Polsce za pomocą sowieckich bagnetów. Nic zatem dziwnego, że od początku swojego warszawskiego pontyfikatu starał się on czynić wszystko, by ożywić świadomość chrześcijańskiej wiary wśród rodaków, zwłaszcza mieszkańców stolicy, która jak żadne inne polskie miasto doznała okrucieństw wojny. Szczególnej szansy w realizacji powziętego zamiaru salezjański kardynał zaczął upatrywać w odnowionych bractwach kościelnych (konfraterniach) funkcjonujących na ziemiach polskich od wieków, zwłaszcza bractwie św. Anny, skupiającym młodzież akademicką i inteligencję katolicką. W ten sposób prymas Polski mimowolne wpisał się w ogólnokościelny trend, któremu patronował papież Pius XII, wyrażony ex cathedra w konstytucji apostolskiej Provida Mater Ecclesia z 2 lutego 1947 roku². W świetle tego dokumentu Kościół katolicki miał się otworzyć na różnego rodzaju organizacje tworzone bądź odnawiane przez katolików świeckich w celu apostolskiego oddziaływania na wiernych.

Zarówno postawę prymasa Polski,jaki decyzję papieża możnaw tym kontekście dostrzec jako symbol zrozumienia czasów, w których przyszło im żyć. Czasów dowartościowania laikatu i przygotowania go do działalności ewangelizacyjnej. Otwartość ta, okazana niemal na dwie dekady przed rozpoczęciem obrad Soboru Watykańskiego II, staje się symptomatyczna, a fakt, że jednym z prekursorów tej postawy był prymas A. Hlond, stawia go w szeregu najbardziej zasłużonych postaci Kościoła XX wieku. Znamienna w tym kontekście staje się przede wszystkim sama konfraternia św. Anny w Warszawie, której przypisano ambitne cele współodpowiedzialności za odnowę religijną wiernych zamieszkujących stolicę.

\section{Z dziejów bractwa św. Anny na ziemiach polskich}

Bractwa kościelne zaczęły powstawać na ziemiach polskich w okresie średniowiecza ${ }^{3}$. Najstarsze $\mathrm{z}$ nich zaczęły się rozwijać $\mathrm{w}$ miastach śląskich i małopolskich od XIII wieku, stając się przestrzenią integracji określonych grup społecznych lub zawodowych. W celu pełniejszej realizacji powziętych zamiarów poszczególne bractwa obierały sobie wezwania, które stanowiły tajemnice przeżywanej wiary, tytuły chrystologiczne i mariologiczne oraz imiona Świętych

${ }^{1}$ Kompleksowo problemem tym zajął się prof. Jerzy Pietrzak. Zob. J. Pietrzak, Pelnia prymasostwa. Ostatnie lata prymasa Polski kardynała Augusta Hlonda 1945-1948, t. 1-2, Poznań 2009.

2 Konstytucja apostolska Provida Mater Ecclesia, „Acta Apostolicae Sedis”, 39 (1947) s.114-124.

${ }^{3}$ K. Kuźmak, Bractwo kościelne, w: Encyklopedia katolicka, t. 2, red. F. Gryglewicz, Lublin 1976, kol. 1013-1016; H.E. Wyczawski, Przygotowanie do studiów w archiwach kościelnych, red. T. Moskal, A.K. Sitnik, Kalwaria Zebrzydowska 2013, s. 313-317. Tam też szczegółowa bibliografia odnosząca się do funkcjonowania bractw. 
Pańskich i pod ich sztandarem wykonywały swoje zamierzenia. Każdemu z bractw przyświecały z góry określone cele dewocyjne lub społeczne (zwłaszcza o charakterze charytatywnym i edukacyjnym ${ }^{4}$.

Wśród konfraterni funkcjonujących na ziemiach polskich szczególnym znaczeniem od XVI wieku zaczęło cieszyć się bractwo św. Anny, przeszczepione do Polski z Niemiec. Początkowo, tak jak i inne bractwa, miało ono charakter typowo dewocyjny i społeczny, z czasem jednak - pod wpływem reform arcybiskupa lwowskiego Jana Dymitra Solikowskiego - zostało przekształcone w towarzystwo, któremu przyświecała obrona Kościoła katolickiego i jego doktryny przed wpływami idei reformacyjnej, godzącej szczególnie w dogmaty o bóstwie Syna Bożego i Ducha Świętego. W ten sposób od 1578 roku przy warszawskim kościele św. Anny, administrowanym przez bernardynów, zaczęło funkcjonować bractwo podejmujące walkę z rozprzestrzeniającymi się wpływami protestanckimi i ariańskimi, któremu patronowała matka Najświętszej Maryi Panny - św. Anna ${ }^{5}$. Jako że konfraterni tej zlecono zadanie przyciągnięcia do Kościoła katolickiego jak największej liczby osób, które od niego odeszły, stąd też zatroszczono się o zapewnienie jej stosownej regulacji prawnej. I na płaszczyźnie legislacyjnej arcybiskup J.D. Solikowski okazał się człowiekiem przewidującym. Ułożył bowiem czternastopunktowy statut, w którym zawarł nie tylko zadania konfraterni, lecz także przedstawił ideał życia chrześcijańskiego. W myśl tychże ustaw każdy katolik wpisujący się w poczet bractwa powinien: znać przynajmniej w stopniu dostatecznym naukę wiary katolickiej; codziennie uczestniczyć we Mszy św.; systematycznie rozważać tajemnice Męki Pańskiej; we wtorki brać udział w Eucharystii sprawowanej ku czci św. Anny odprawianej u bernardynów w Krakowie, Warszawie, Wilnie, we Lwowie bądź innym z większych miast Rzeczypospolitej; w ważniejsze święta spowiadać się i przystępować do Komunii św. lub - nie mogąc sprostać temu zaleceniu - złożyć stosowną jałmużnę; unikać pijaństwa i obmowy, a także innych grzechów gorszących bliźnich; przeciwdziałać wszelkim wypowiedziom przeciwko Kościołowi i religii; ćwiczyć się w pokorze i cierpliwości; potrafić udzielać koniecznych napomnień; nosić na szyi znak bractwa z wyobrażeniem św. Anny Samotrzeć; uczestniczyć w corocznych wyborach przełożonego (tzw. starszego) bractwa; organizować posiedzenia konfraterni tylko w godnym miejscu (kościele lub kaplicy); troszczyć się o stan skarbony i księgę bracką, obie przechowując w kościele; łożyć według własnych możliwości na cele charytatywne i statutowe; składać ofiary na pogrzeb stowarzyszonych w bractwie zmarłych współbraci; uczestniczyć w żałobnym nabożeństwie sprawowanym za zmarłych konfratrów nazajutrz po wspomnieniu św. Anny i po uroczystości poświęcenia kościoła lub kaplicy. Ponadto każdy członek bractwa został zobowiązany do codziennego odmawiania koronki i przypisanej modlitwy do św. Anny lub w ich miejsce zmówienia pięciu pacierzy do Pięciu Ran Pana Jezusa, za

${ }^{4}$ B. Kumor, Kościelne stowarzyszenia świeckich na ziemiach polskich w okresie przedrozbiorowym, w: Księga 1000-lecia katolicyzmu w Polsce, t. 1, red. M. Rechowicz, Lublin 1969, s. 507-508.

${ }^{5}$ K. Kuźmak, Anna św. III, w: Encyklopedia katolicka, t. 1, red. F. Gryglewicz, Lublin 1973, kol. 626. 
Kościół święty i za religię katolicką ${ }^{6}$. Ustawy te po trzech latach od sformułowania zostały zatwierdzone przez Giovanni Anderea Caligari, nuncjusza apostolskiego w Polsce, na mocy dekretu His, quae pro z 11 czerwca 1581 roku. W 1589 roku papież Sykstus V bullą Ex incumbenti podniósł warszawską konfraternię św. Anny do rangi arcybractwa i obdarzył ją licznymi przywilejami. Uhonorowanie to niosło ze sobą m.in. przywilej agregacji (tj. przyłączenia) do konfraterni funkcjonującej w stolicy wszystkich innych bractw o tej samej nazwie z terenu Rzeczpospolitej Obojga Narodów. Bulla papieska przyczyniła się do dynamicznego rozwoju bractwa, a w konsekwencji do erygowania nowych jego oddziałów. Opiekę nad nimi powierzono bernardynom, którzy propagowali bractwo wśród pielgrzymów przybywających do administrowanych przez nich sanktuariów. Do grona konfratrów bractwa św. Anny dołączyli m.in. król Zygmunt III Waza, jego żona - Anna oraz kanclerz Jan Zamoyski ${ }^{7}$. O wspomnianej z imienia królowej akta warszawskiego klasztoru Bernardynów wspominają, że co wtorek wraz z licznym orszakiem duchownych i świeckich dworzan brała udział we mszach brackich, a gdy zdarzyło się, że któraś z dam lub panien z dworu nie przybyła na Eucharystię, wówczas królewska małżonka dopytywała się o przyczynę absencji. Przy błahym powodzie upominała nieobecne, by w przyszłości sumiennie wypełniały obowiązki wynikające $\mathrm{z}$ przynależności do bractwa ${ }^{8}$. Przykład ten stanowi świadectwo znaczenia konfraterni, do której należała elita ówczesnej władzy. Gorliwością w spełnianiu powinności brackich wykazywał się także kanclerz królestwa i hetman wielki koronny - Jan Zamoyski. Jemu to zadedykowano wydaną w 1599 roku w Zamościu książeczkę noszącą tytuł Societas Sanctae Annae, świadczącą o wsparciu kanclersko-hetmańskim dla bractwa św. Anny ${ }^{9}$. Przełom XVI i XVII wieku stanowił niewątpliwie najkorzystniejszy okres w dziejach konfraterni. Nie oznacza to jednak, że i później nie wstępowali do niej prominentni konfratrzy, a papieże (np. Benedykt XIV) obdarzali je stosownymi odpustami. Dzięki temu do końca istnienia Rzeczpospolitej szlacheckiej na jej terytorium funkcjonowały bractwa św. Anny w Warszawie, Krakowie, Wilnie, we Lwowie, jak i wielu pomniejszych miejscowościach ${ }^{10}$.

Czasem próby dla bractwa okazał się okres niewoli narodowej. Zaborcy czynili wiele starań, żeby ograniczyć jego oddziaływanie. Szczególnie trudna sytuacja dotknęła konfraternię funkcjonującą przy kościele Bernardynów w Warszawie. Władze carskie zarzuciły jej szereg nieprawidłowości, z nadużyciami finansowymi włącznie. Z pomocą bractwu przyszedł wówczas gwardian bernardynów w Warszawie - o. Laurenty Długokęcki. Opracował on dziewięciopunktowy program reformistyczny przewidziany dla bractwa, a następnie przesłał go do

${ }^{6}$ S. Chodyński, Bractwo, w: Encyklopedia Kościelna. Podtug teologicznej encyklopedji Wetzera i Weltego z licznemi jej dopetnieniami, t. 2, red. M. Nowodworski, Warszawa 1873, s. 571.

${ }^{7}$ Kuźmak, Anna, kol. 626.

${ }^{8}$ Chodyński, Bractwo, s. 571.

${ }^{9}$ Tenże, Anny św. bractwo, w: Encyklopedia Kościelna, t. 1, red. M. Nowodworski, Warszawa 1873 , s. 259

${ }^{10}$ S. Litak, Struktura i funkcje parafii w Polsce, w: Kościół w Polsce, t. 2: Wiek VI-XVIII, red. J. Kłoczowski, Kraków 1969, s. 463. 
władz państwowych (a nie do konsystorza warszawskiego) w celu zatwierdzenia. Krok ten skutkował zachowaniem konfraterni przy jednoczesnym zastrzeżeniu, że odtąd będzie ona podlegała rektorowi kościoła, przy którym funkcjonowała. Dzięki temu udało się uchronić bractwo przed nieuchronną likwidacją, przynajmniej do $1864 \mathrm{roku}^{11}$. Sytuacja, która się wytworzyła po upadku powstania styczniowego pod wpływem wszechobecnych represji carskich skutkujących zwłaszcza kasatą zakonów - negatywnie wpłynęła na i tak już osłabioną pozycję konfraterni. W zaistniałej sytuacji musiała ona zawiesić swoją działalność. Była to niewątpliwa strata dla katolicyzmu w zaborze rosyjskim, zważywszy na znaczenie bractwa w przeszłości. Jego tradycja była jednak żywa. Nic zatem dziwnego, że nawiązał do niego prymas A. Hlond w sytuacji, gdy chciał odnowić ducha warszawiaków po 1945 roku, a jednocześnie pragnął posiadać organizację oddziałującą religijnie w stolicy, zdominowanej przez nową władzę, nieprzychylną Kościołowi.

\section{Kontekst odnowy ustaw i regulaminu bractwa}

Bractwo św. Anny w Warszawie, co już zaznaczono, posiadało swoje statuty zatwierdzone w 1581 roku przez ówczesnego nuncjusza apostolskiego w Polsce G.A. Caligariego. Część z nich jednak odstawała do nowych czasów, jak i obowiązującego od 1918 r. Kodeksu Prawa Kanonicznego, stąd też powojenni odnowiciele konfraterni postanowili uwspółcześnić te artykuły, które nie korespondowały z aktualną sytuacją eklezjalną. W tym celu wprowadzono korektę w kilku punktach, a mianowicie w II, III, IV, VIII, X oraz XIV ${ }^{12}$. Dodatkowo nadano konfraterni regulamin uściślający pozycję i rolę warszawskiego bractwa św. Anny.

Pragnienie reaktywacji zasłużonej dla polskiego katolicyzmu konfraterni musiało jednak zostać usankcjonowane wolą i autorytetem ordynariusza miejsca, a więc prymasa A. Hlonda. W tym celu złożono na jego ręce przygotowany 8 grudnia 1946 roku projekt statutowy, który został poddany rewizji i niezbędnym uzupełnieniom. Prace nad nimi rozpoczął osobiście kardynał A. Hlond i w piśmie z 29 maja 1947 roku poinformował zarząd bractwa św. Anny w Warszawie, że zaaprobuje przedstawione mu ustawy, jeżeli zostanie dodany do nich dodatkowy XV artykuł, o następującym brzmieniu: „Bractwo św. Anny podlega jurysdykcji i nadzorowi miejscowego ordynariusza w myśl Kodeksu Prawa Kanonicznego (kan. 690 §1 i nast.)". W wyekspediowanej 3 czerwca 1947 roku odpowiedzi informował ponadto zarząd bractwa, że po dokonanej korekcie ustawy powinny ponownie trafić do kurii (w 3 egzemplarzach) w celu ich ostatecznego zatwierdzenia ${ }^{13}$. Zastrzeżenie to okazało się istotne, zważywszy na to, że po raz drugi prymas zajął się osobiście korektą ostatecznej wersji ustaw. Własnoręcznie naniósł poprawki w punkcie 12 regulaminu, zamieniając zapis: „Do ważniejszych

${ }^{11}$ W.F. Murawiec, Bernardyni warszawscy. Dzieje klasztoru św. Anny w Warszawie 1454-1864, Kraków 1973, s. 147-148.

${ }_{12}$ Archiwum Archidiecezjalne w Gnieźnie (dalej: AAG), Archiwum Prymasa Polski (dalej: APP) [1945-1948], Bractwa kościelne [1946-1948], b. sygn., k. 2-4.

${ }^{13}$ Tamże, k. 1. 
uchwał Towarzystwa wymagana jest zgoda Promotora" na radykalniej brzmiące określenie: „Do wszystkich uchwał Towarzystwa wymagana jest zgoda Promotora" 14 . Ponadto wykreślił w regulaminu rozdział V (pt. Oddziały), z zawartym w nim punktem 20. Ten bowiem stanowił: „Towarzystwo może mieć autonomiczne oddziały we wszystkich akademickich miastach polskich za zezwoleniem miejscowego ordynariusza na podstawie prawa kościelnego regulującego stosunek prawny bractw kościelnych do arcybractwa"15. Były to już ostatnie zmiany poczynione przez prymasa. W myśl kanonu 689 Kodeksu Prawa Kanonicznego ustawy i regulamin bractwa w formie wygotowanego dokumentu zostały podpisane przez ordynariusza 30 września 1947 roku, a kontrasygnowane przez ks. dra Antoniego Baraniaka. Mimo to oficjalna data widniejąca na czystopisie dokumentu to 8 września 1947 roku (święto Narodzenia NMP). Nieco dłużej trwała ekspedycja pisma. Odpowiedzialny za nią ks. Władysław Padacz rozesłał statuty bractwa do zainteresowanych stron dopiero 22 października $1947 \mathrm{roku}^{16}$.

\section{Cele i zasady wydawnictwa źródłowego}

Głównym powodem skłaniającym do wydania Ustaw zasadniczych bractwa św. Anny w Warszawie była chęć ukazania roli, jaką w powojennej polskiej rzeczywistości odegrały odradzające się bractwa kościelne. W swoich szeregach grupowały one ludzi uświadomionych religijnie, którzy pragnęli dzielić się $\mathrm{z}$ innymi doświadczeniem życiowym oraz przeżywaną wiarą. Ta płaszczyzna życia eklezjalnego, charakterystyczna dla wielowiekowej tradycji katolicyzmu na ziemiach polskich, niestety nadal jest słabo rozpoznana. Należy ją zatem nie tylko dostrzec, ale przede wszystkim przybliżać jak najszerszemu gronu odbiorców, by w ten sposób ukazać wkład Kościoła katolickiego w odbudowę tożsamości narodowej i konfesyjnej w nieprzychylnym okresie powojennym, gdy pod auspicjami potężnego Związku Sowieckiego rodziło się w Polsce państwo komunistyczne, wrogie dotychczasowym wartościom Polaków. Znamienna rola w tym ideologicznym boju przypadła m.in. bractwu św. Anny w Warszawie.

Za podstawę niniejszego wydania posłużył maszynopis Ustaw zasadniczych bractwa św. Anny w Warszawie, przechowywany w Archiwum Archidiecezjalnym w Gnieźnie ${ }^{17}$. Jest on częścią powojennego Archiwum Prymasa Polski (obecnie w trakcie opracowywania). Dodatkowo - w celach porównawczych - zestawiono go z wcześniejszym brzmieniem ustaw z 21 kwietnia 1581 roku $^{18}$, by w pełni ukazać legislacyjna wkład prymasa A. Hlonda w reformę bractwa św. Anny w Warszawie.

\footnotetext{
14 Tamże, k. 10v.

15 Tamże, k. 10v-11r.

16 Tamże, k. 9v.

17 Tamże, k. 8-11.

18 Tamże, k. 2-7.
} 
Przygotowując niniejszą kopię wydawniczą, dostosowano się do wskazówek edytorskich sugerowanych przez adekwatną dla tego okresu historycznego instrukcję wydawniczą, opracowaną przez Ireneusza Ihnatowicza ${ }^{19}$.

\section{USTAWY ZASADNICZE BRACTWA ŚW. ANNY z 21 IV 1581 r. wraz ze zmianami z 8 XII 1946 r. $^{20}$}

\section{Bractwo św. Anny}

Na chwałę i cześć Boga Wszechmogącego i na pociechę wiernych chrześcijan, dla powiększenia ich wiary, nadziei i miłości i dla powszechnego pożytku ustanowione i przyjęte po całej Polsce.

Psalm LXI:

Owocem miłości - zbawienie

„Ufajcie w Bogu, wszystko zgromadzenie ludu, otwórzcie ku Niemu serca wasze. Bóg wspomożeniem naszym na wieki”.

Aby Bractwo, albo Towarzystwo św. Anny, Matki Bożej Rodzicielki Dziewicy Maryi większą pobożnością, poszanowaniem i pożytkiem przyjęte było, ku chwale i czci Jedynego i Prawdziwego Boga, którego należy wielbić w Trójcy Świętej;

aby pilniej rozpamiętywało dobrodziejstwa Boże, udzielone nam za wstawiennictwem św. Anny - bezcennej Świątyni Bożej i Jej Córki, Niepokalanej w narodzeniu naszego Zbawiciela Dziewicy;

aby wzrastało i zbierało należne plony my, współbracia tego Towarzystwa spisaliśmy po starannym zbadaniu te ustawy generalne, do których zachowania i przy pomocy Bożej wypełnienia, oraz do nigdy ich nieprzestąpienia zobowiązaliśmy się w dobrym i chrześcijańskim związku, dobrowolnie i chętnie, nas samych, oraz tych, którzy następnie do tego Towarzystwa przyjęci zostaną.

\section{Artykuł I}

Każdy z nas Modlitwę Pańską, Pozdrowienie Anielskie, Wyznanie Wiary katolickiej oraz Dziesięcioro Przykazań powinien znać, przestrzegać i odmawiać z dziećmi swymi i ze swą rodziną, każdy w swym domu.

\section{Artykuł II}

Z czcią i pobożnością spełniać obowiązki katolika nakazane przez Kościół. Ponadto pogłębiać swe życie religijne przez w miarę możności codzienne

${ }^{19}$ I. Ihnatowicz, Projekt instrukcji wydawniczej dla źródeł historycznych XIX i poczatku XX wieku, „Studia Źródłoznawcze”, 12 (1965/1966) s. 99-123. Przedruk: J. Tandecki, K. Kopiński, Edytorstwo źródet historycznych, Warszawa 2014, s. 385-412.

${ }^{20}$ Zaakceptowanymi i zatwierdzonymi przez A. Hlonda 30 września 1947 roku. Zob. AAG, APP [1945-1948], Bractwa kościelne [1946-1948], b. sygn., k. 8-9. 
rozmyślanie i czytanie dzieł religijnych, a przede wszystkim Pisma Świętego Nowego Testamentu, oraz brać czynny udział w modlitwach liturgicznych Mszy św. ${ }^{21}$

\section{Artykuł III}

Prócz czasu ustanowionego przez święty Kościół katolicki i innych terminów według zwyczaju i praktyki pobożnej każdego, w dniu Zesłania Ducha Świętego, Niepokalanego Poczęcia Najświętszej Maryi Panny i św. Anny pobożnie przyjąć Przenajświętszą Eucharystię 22 .

\section{Artykuł IV}

Unikać pijaństwa i wszelkich gorszących czynów. Unikać zgorszenia bliźnich, jest to bowiem zgubna i wstrętna choroba. Nikomu nie szkodzić mową ani czynem, raczej wszystkim pomagać, służyć pomocą jej potrzebującym przez szczodrobliwość, radę i pociechę. Uspakajać niezgody między wiernymi, przyczyniać się do ich pogodzenia się, o każdym dobrze myśleć i zamierzać, nikogo nie podchodzić podstępem, lichwą lub zdradą, lecz ze wszystkimi słusznie i rzetelnie obcować w każdym działaniu.

Możliwie dnia każdego wzbudzić w sobie z czystej miłości dla Pana naszego Jezusa Chrystusa żywą chęć dopomożenia jakiemu bądź bliźniemu w potrzebie jego duchowej lub cielesnej i chęć tę wykonać starannie dobranym uczynkiem.

Ilekroć o wspólną pracę idzie lub ilekroć członek Towarzystwa będzie dzierżył władzę lub władzy podlegał - stosować najstaranniej naukę Kościoła o stosunkach w społeczności oraz o pochodzeniu i wykonywaniu władzy ${ }^{23}$.

${ }^{21}$ Artykuł II ustaw z 1581 roku stanowił: „Z wielką czcią, pobożnością i skupieniem uczestniczyć co dzień w ofierze Mszy Św.; podczas niej rozmyślać Mękę Pana i Zbawiciela naszego Chrystusa i za Niego składać Bogu dzięki. Co wtorek podczas Mszy św. jest we zwyczaju śpiewać o św. Annie u braci Bernardynów w Krakowie, w Wilnie, w Warszawie, Lwowie, a gdziekolwiek w Koronie, Litwie i na Rusi, czy też w innych miejscach w kościołach parafialnych i w kaplicach wzniesionych z pobożności ludzkiej zwykło się rozważać żywot św. Anny, Błogosławionej Dziewicy Maryi oraz Narodzenie i Wcielenie Pana Naszego Odkupiciela. Nieobecni z powodu prawdziwie ważnych zajęć mogą być usprawiedliwieni”. Zob. tamże, k. 11.

${ }^{22}$ Artykuł III ustaw z 1581 roku brzmiał: „Prócz czasu ustanowionego przez święty Kościół katolicki i innych terminów według zwyczaju i praktyki pobożnej każdego, w dniu św. Anny wyznawać pokornie swe grzechy Bogu i właściwemu kapłanowi i pobożnie przyjąć Przenajświętszą Eucharystię. Ci, którym uniemożliwią to nieprzewidziane okoliczności, wpłacą obfitszą jałmużnę na biednych". Zob. tamże.

${ }^{23}$ Artykuł IV ustaw z 1581 roku był krótszy, zawierał jedynie stwierdzenie: „Unikać pijaństwa i wszelkich gorszących czynów. Unikać zgorszenia bliźnich, jest to bowiem zgubna i wstrętna choroba. Nikomu nie szkodzić mową, ani czynem, raczej wszystkim pomagać i służyć pomocą jej potrzebującym przez szczodrobliwość, radę i pociechę. Uspakajać niezgody między wiernymi, przyczyniać się do ich pogodzenia się o każdym dobrze myśleć i zamierzać, nikogo nie podchodzić podstępem, lichwą lub zdradą, lecz ze wszystkimi słusznie i rzetelnie obcować w każdym działaniu". Zob. tamże, k. 12. 


\section{Artykuł V}

Jeśli zdarzy się nam słyszeć kogoś mówiącego przeciw świętemu Kościołowi katolickiemu i Jego nauce, albo szczególnie przeciw Synowi Bożemu i przeciw Duchowi Świętemu, co o zgrozo bezkarnie uchodzi, albo przeciw siedmiu sakramentom Kościoła, albo przeciw Świętym Pańskim, albo co gorsza, ośmieszającego te świętości - bluźnierstw jego nie przyjmować milczeniem, lekceważeniem albo milczącą zgodą lecz stosownie do swej wiedzy, łagodnie i z katolickim umiarkowaniem zawsze odpowiedzieć, aby głupi nie zdał się sobie mądrym. Komu zaś brak wiedzy, powinien jednak powiedzieć, że mu się to nie podoba i że Kościół uczy inaczej. A gdyby ów heretyk nie zaprzestał, lecz chciał kończyć swe słowa, wstać od niego i, jak mówi św. Jan Ewangelista o Koryncie, jak najszybciej uciec i odstąpić, aby gniew Boży nie naszedł niespodzianie na bluźniących.

\section{Artykuł VI}

I chociaż zazwyczaj obracamy się wśród pomyślności i przeciwności, które niejednakowo znosimy, zaleca się, żebyśmy bracia tego Towarzystwa, jeden i drugi los spokojnie, znosili. W rzeczach pomyślnych nie wynosić się, ani zapominać o Bogu, lecz raczej uznawać, że otrzymane zostały od Niego, dziękować za nie Bogu, ani wynosić się w pysze, albo upodobać w sobie, albo cokolwiek sobie przypisywać. W smutkach zaś nie szemrać, lecz zdawać się na wolę Bożą i wspominać ofiarę Pana naszego Zbawiciela, Najświętszej Maryi Panny i św. Anny i wszystkich Świętych, którzy w przeciwnych i smutnych okolicznościach zawsze posłuszni byli Bogu i poddani Jego woli.

\section{Artykuł VII}

Chociaż wszyscy stanowimy kruche naczynia i tak jesteśmy ulegający upadków i wad, postanowiono, aby każdy z nas innego brata Towarzystwa napominał i z braterską miłością $\mathrm{z}$ powodu jego wad, o których by na pewno wiedział, że je popełnił i aby jego ostrzegł, co przez napominanego brata powinno być przyjęte wdzięcznie i bez urazy, nawet z podziękowaniem.

\section{Artykuł VIII}

Hasłem Towarzystwa są trzy słowa: FRUCTUS CHARITATIS SALUS OWOCEM MIŁOŚCI - ZBAWIENIE. Zaleca się braciom nosić zwyczajem przyjętym przez świeckie stowarzyszenia znak z hasłem Towarzystwa na nim wypisanym $^{24}$.

${ }^{24}$ Artykuł VIII ustaw z 1581 roku stanowił: „Każdy z nas będzie nosił jako symbol, czy też znak Towarzystwa złoty, srebrny, albo brązowy medal zawieszony na szyi na łańcuszku lub taśmie, $w$ ten sposób, jak zwykło się nosić na cześć ziemskich władców, co z jednej strony z wytłoczonym wizerunkiem św. Anny, Błogosławionej Dziewicy Maryi i Pana Jezusa na ich łonie, wyrażony według przyjętego zwyczaju, z napisem wokół: SANCTAE ANNAE SOCIETAS, drugiej zaś strony napisane wprost te trzy słowa: FRUCTUS CHARITATIS SALUS. Zob. tamże. 


\section{Artykuł IX}

Każdego roku winien być obrany jeden brat starszy, który pouczony przez innych o swych obowiązkach, oznacza czas wspólnych zebrań i będzie kierownikiem całego porządku prac oraz dobrego działania i karności.

\section{Artykuł X}

Na wszystkich swych zebraniach, które będą się odbywały w kościele św. Anny, czy też innym godnym miejscu, obok miejsc poświęconych świętej Annie, bracia powinni zachowywać się $\mathrm{z}$ całą skromnością i godnością i nie czynić tam żadnych innych rzeczy, jak tylko te, które mają na względzie potrzeby tego Towarzystwa ${ }^{25}$.

\section{Artykuł XI}

Skarbiec i archiwum Towarzystwa będą przechowywane w świątyni, klucze od nich będą u starszego i drugiego brata, wybranego przez zgromadzenie. Do skarbca będą wnoszone doroczne składki na Kościół, kapłanów i biednych miejscowych. Jak to zostanie postanowione każdego roku, bracia i siostry dający swe nazwiska do tego Towarzystwa i wpisujący się do księgi Towarzystwa, która będzie zawsze przechowywana w kościele, zobowiążą się każdy, według swego uznania, ile wyznaczą jako jałmużnę na kościół i podadzą wartość i sumę, którą mają zamiar dać na święto św. Anny.

\section{Artykuł XII}

Bracia i siostry wpisujący się do księgi Towarzystwa będą używali tej lub podobnej formuly: „Ja NN wpisuję się do tego Towarzystwa św. Anny i przyrzekam, że będę jemu służył na chwałę Boga i na wzrost i pożytek Świętego Jego Kościoła katolickiego. Na potrzeby tego Towarzystwa i kościoła i biednych corocznie póki będę żył i gdziekolwiek będę, jeśli będę mógł, dawać będę ... zł, jako jałmużnę. Napisałem dnia... miesiąca... roku...”.

\section{Artykuł XIII}

Gdy zaś brat lub siostra tego Towarzystwa przeniesie się $\mathrm{z}$ tego nędznego życia do tamtego niebieskiego, każdy z nas weźmie udział w jego pogrzebie i odda zmarłemu ostatnią posługę w Chrystusowej miłości. Egzekwie jego obchodzić będzie uroczystymi ceremoniami, modlitwą i jałmużną. Nieobecni zadośćuczynią swej usprawiedliwionej nieobecności jałmużną, którzy będą mogli, i modlitwami do Boga za jego duszę.

${ }^{25} \mathrm{~W}$ artykule $\mathrm{X}$ ustaw z 1581 roku nakazano, by: „Na wszystkich swych zebraniach, które się będą odbywały w kościele albo w kaplicy św. Anny u Braci Bernardynów, w mieszkaniu znakomitszych osób czy też innym godnym miejscu, obok miejsc poświęconych św. Annie, bracia powinni się zachowywać z całą skromnością i godnością i nie czynić tam żadnej innej rzeczy, jak tylko te, które mają na względzie potrzeby tegoż Towarzystwa. Kobiety nie będą uczestniczyły w tych zebraniach, lecz będą przez przewodniczącego pouczone z urzędu o tym, co zostało przez braci postanowione". Zob. Tamże, k. 13. 


\section{Artykuł XIV}

Dwa razy do roku urządzana będzie żałobna Msza św. za zmarłych braci i siostry tego Towarzystwa. Bracia i siostry powinni brać udział w tych Mszach św., składając, którzy mogą, ofiary według zwyczaju ${ }^{26}$.

\section{Artykuł XV}

Bractwo św. Anny podlega jurysdykcji i nadzorowi miejscowego ordynariusza w myśl Kodeksu Prawa Kanonicznego (kan. 690 §1 i nast.).

\section{REGULAMIN BRACTWA ŚW. ANNY PRZY KOŚCIELE AKADEMICKIM ŚW. ANNY W WARSZAWIE ${ }^{27}$}

\section{I. Środki dla osiągnięcia celów}

1. Towarzystwo w miarę możności pomaga duszpasterzowi akademickiemu w organizowaniu i prowadzeniu pracy przy kościele akademickim w Warszawie.

2. Towarzystwo propaguje udział wiernych we Mszy św. przez Msze św. recytowane i urządza takie Msze św. dla członków, organizuje rekolekcje otwarte i zamknięte, bierze udział w uroczystych nabożeństwach w kościele św. Anny.

3. Towarzystwo organizuje sekcje studiów religijnych i inne sekcje specjalne, organizuje zebrania dyskusyjne na tematy religijne i prowadzi bibliotekę religijną.

4. Towarzystwo organizuje samopomoc dla swych członków, zwłaszcza posiadających dużą liczbę dzieci.

\section{Członkowie}

5. Członkiem Towarzystwa może zostać każdy świecki lub duchowny, kto był studentem wyższej uczelni, albo, za specjalną zgodą Zarządu, posiadający przynajmniej pełne przygotowanie do wyższych studiów, jest praktykującym katolikiem, został wprowadzony przez dwóch członków wprowadzających i po przynajmniej 6-miesięcznej kandydaturze został przyjęty przez Zarząd

${ }^{26} \mathrm{~W}$ myśl statutów z 1581 roku nakazano, by: „Dwa razy do roku urządzane będą ogólne egzekwie i żałobna Msza św. za zmarłych braci i siostry tego Towarzystwa, Po pierwsze nazajutrz po święcie św. Anny, Jeśliby to wypadło w niedzielę, przeniesione zostanie na poniedziałek w dniu święta niezastrzeżonego. Po drugie nazajutrz po dniu ofiarowania kościoła św. Annie, co zwykło się dziać dnia... Bracia i siostry powinni brać udział w tych egzekwiach i Mszach Św., a którzy nie mogą, czynić ofiary według zwyczaju. Koronka do św. Anny według dawnego obyczaju razem z innymi dobrymi rzeczami zaniechana i zaniedbana w tym wieku tak niewdzięcznym względem Boga i pogańskim, lecz jednak zachowana przez pobożnych i świątobliwych ludzi, a zwłaszcza święte matrony, będzie odmawiana w pewnych terminach przez ludzi mniej zajętych według upodobania w ten sposób, który wyjaśni przewodniczący lub spowiednik. Lecz w pewne dni wszyscy są obowiązani do odmawiania następujących modlitw, którzy zaś nie umieją czytać, powinni zamiast przepisanych modlitw odmawiać w pewne dni po pięć Ojcze Nasz i Zdrowaś dla uczczenia Pięciu Ran Pana Naszego Jezusa Chrystusa i modlić się za Kościół Święty Katolicki, Najjaśniejszego naszego Króla i nawrócenia heretyków". Zob. tamże.

${ }^{27}$ Tamże, k. 10r-11r. 
Towarzystwa. Kandydatura winna być podana do wiadomości wszystkich członków przez ogłoszenie na najbliższym zebraniu miesięcznym Towarzystwa.

6. Członkowie mają obowiązek:

a) spełniać obowiązki moralne wynikające $\mathrm{z}$ ustaw zasadniczych Towarzystwa;

b) brać udział w miesięcznych Mszach św. i zebraniach Towarzystwa;

c) przystępować wspólnie do Komunii św. w dniach Zesłania Ducha Świętego, Niepokalanego Poczęcia Najświętszej Maryi Panny i św. Anny.

d) brać $\mathrm{w}$ miarę możności udział $\mathrm{w}$ pracach Towarzystwa i sumiennie wykonywać obowiązki na siebie wzięte;

e) płacić składki w wysokości co rok ustalonej przez każdego członka, nie mniejszej jednak od uchwalonej przez ogólne doroczne zebranie Towarzystwa. W wyjątkowych wypadkach Zarząd ma prawo zwolnić z płacenia składki.

f) brać udział w miarę możności w dwóch dorocznych Mszach św. za zmarłych członków, a mianowicie w miesiącach październiku oraz czerwcu, jako początku i końcu roku akademickiego.

7. Członkowie mają prawo:

a) korzystania z wszelkich urządzeń Towarzystwa;

b) bierne i czynne prawo wyborcze do władz Towarzystwa.

8. Członkiem przestaje się być:

a) przez pisemne zgłoszenie swego wystąpienia do Zarządu, co jednocześnie zwalnia od obowiązku uregulowania zaległych zobowiązań materialnych;

b) na skutek orzeczenia sądu Towarzystwa, z powodu sprzeniewierzenia się ideałom katolickim lub popełnienia czynu haniebnego;

c) na skutek skreślenia przez Zarząd $\mathrm{z}$ listy członków $\mathrm{z}$ powodu nieusprawiedliwionego nie brania udziału $\mathrm{w}$ życiu Towarzystwa przez okres dłuższy niż 6 miesięcy.

\section{Sekcje}

9. Dla osiągnięcia celów Towarzystwa Zarząd powołuje sekcje.

10. Sekcje samokształceniowe nie mogą liczyć więcej niż 20 członków.

11. Sekcje osądzą się własnymi regulaminami wewnętrznymi zatwierdzanymi przez Zarząd.

\section{Władze}

12. Promotorem Towarzystwa jest Rektor kościoła akademickiego, spełniający obowiązki promotorstwa sam bezpośrednio lub przez wyznaczonego przez niego kapłana. Do ważniejszych uchwał Towarzystwa wymagana jest zgoda Promotora.

13. Ogólne zebranie braci /sióstr/ jest zwoływane przez Zarząd przynajmniej raz do roku.

Celem wybrania władz Towarzystwa, zatwierdzenia sprawozdania ustępujących władz, uchwalenia programu prac na następny rok pracy oraz stanowienia we 
wszelkich sprawach dotyczących Towarzystwa ogólne zebranie odbywać się będzie w miesiącu czerwcu. Zebranie wyborcze może być jednocześnie zebraniem przewidzianym w ustępie pierwszym tegoż paragrafu.

14. Nadzwyczajne ogólne zebranie zwołuje Zarząd najdalej w 6 tygodni po otrzymaniu pisemnego żądania przynajmniej 20 członków lub na żądanie Komisji Rewizyjnej.

15. Termin ogólnego zebrania winien być podany do wiadomości członków na miesięcznym zebraniu oraz powinien być ogłoszony w lokalu Towarzystwa.

16. Zarząd Towarzystwa składa się ze starszego, jako przewodniczącego, jego zastępcy, sekretarza, skarbnika, 2 członków oraz przewodniczących sekcji.

17. Komisja Rewizyjna Towarzystwa składa się z 3 członków i 2 zastępców, wybieranych na okres roku przez Ogólne Zebranie. Komisja Rewizyjna kontroluje działalność władz Towarzystwa i składa sprawozdanie Ogólnemu Zebraniu.

18. Sąd Towarzystwa składa się z 3 członków i 2 zastępców wybieranych na okres roku przez Ogólne Zebranie. Sąd rozstrzyga sprawy sporne powstałe na terenie Towarzystwa oraz rozważa wnioski w sprawie skreślenia z listy członków Towarzystwa.

19. Towarzystwo, jako organizacja kościelna, podlega bezpośrednio władzy miejscowego Ordynariusza, działającego przez Promotora.

\section{BIBLIOGRAFIA}

\section{Źródła rękopiśmienne}

Archiwum Prymasa Polski 1945-1948, Bractwa kościelne [1946-1948] b. sygn.

\section{Wydawnictwa zwarte}

Konstytucja apostolska Provida Mater Ecclesia, w: „Acta Apostolicae Sedis”, 39 (1947) s. $114-124$.

\section{Opracowania}

Chodyński Stanisław, Anny św. bractwo, w: Encyklopedia Kościelna, t. 1, red. M. Nadworski, Warszawa 1873, s. 258-259.

Chodyński Stanisław, Bractwo, w: Encyklopedia Kościelna, t. 2, red. M. Nowodworski, Warszawa 1873, s. 551-577.

Ihnatowicz Ireneusz, Projekt instrukcji wydawniczej dla źródet historycznych XIX i początku XX wieku, „Studia Źródłoznawcze”, 12 (1965/66) s. 99-123.

Kumor Bolesław, Kościelne stowarzyszenia świeckich na ziemiach polskich w okresie przedrozbiorowym, w: Ksiegga 1000-lecia katolicyzmu w Polsce, t. 1, red. M. Rechowicz, Lublin 1969, s. 503-545.

Kuźmak Krystyna, Anna św. III, w: Encyklopedia katolicka, t. 1, red. F. Gryglewicz, Lublin 1973, kol. 625-626.

Kuźmak Krystyna, Bractwo kościelne, w: Encyklopedia katolicka, t. 2, red. F. Gryglewicz, Lublin 1976, kol. 1013-1016. 
Litak Stanisław, Struktura i funkcje parafii w Polsce, w: Kościól w Polsce, t. 2, red. J. Kłoczowski, Kraków 1969, s. 259-481.

Murawiec Wiesław Franciszek, Bernardyni warszawscy. Dzieje klasztoru św. Anny $w$ Warszawie 1454-1864, Kraków 1973.

Pietrzak Jerzy, Petnia prymasostwa. Ostatnie lata prymasa Polski kardynała Augusta Hlonda 1945-1948, t. 1-2, Poznań 2009.

Tandecki Janusz, Kopiński Krzysztof, Edytorstwo źródeł historycznych, Warszawa 2014. Wyczawski Hieronim Eugeniusz, Przygotowanie do studiów w archiwach kościelnych, red. T. Moskal i A.K. Sitnik, Kalwaria Zebrzydowska 2013.

\title{
THE STATUTE AND REGULATIONS OF ST ANNE BROTHERHOOD IN WARSAW IN 1946
}

\begin{abstract}
Summary
Taking over the Archdiocese of Warsaw, joined with the Archdiocese of Gniezno by a personal union, in 1946, Primate August Hlond desired to renew religious and moral life of its faithful (primarily students and people connected with the academic environment) who lived in the war-damaged capital. To achieve this aim he restored St Anne Brotherhood with its tradition dating back to the 16th century and granted it the legal status corresponding with the current church law. He personally made amendments in the bill of 8 December 1946. Work on the bill lasted several months, until 30 September 1947. Thanks to that, St Anne Brotherhood had a legal basis and the support of the Primate of Poland. As a result, it could function among academic and intellectual circles of the capital; it could also propagate Catholicism and form the proper environment for the revival of Christian morality in society depraved by the occupation reality. These tasks were not easy ones, especially when taking account of the post-war reality of the communist state in Poland.

Key words: church brotherhoods; statutes and regulations of brotherhoods; Catholicism; August Hlond; St Anne Brotherhood; the Catholic intelligentsia; academic chaplaincy
\end{abstract}

